\title{
Fluctuating weakness: clue in the eyes!
}

\author{
Amrit Kaur (ㄷ), ${ }^{1}$ Chakshu Chaudhry 이, ${ }^{1}$ Aditi Mehta 이, ${ }^{2}$ Anupriya Kaur ${ }^{1}$
}

${ }^{1}$ Pediatrics, Post Graduate Institute of Medical Education and Research, Chandigarh, India ${ }^{2}$ Advanced Eye Centre, Post Graduate Institute of Medical Education and Research, Chandigarh, India

\section{Correspondence to} Dr Anupriya Kaur; anukaur.genetics@gmail.com

Accepted 30 November 2020
Check for updates

(C) BMJ Publishing Group Limited 2020. No commercial re-use. See rights and permissions. Published by BMJ.

To cite: Kaur A, Chaudhry $C$, Mehta $\mathrm{A}$, et al. BMJ Case Rep 2020;13:e239211. doi:10.1136/bcr-2020239211

\section{DESCRIPTION}

A 9-year-old girl presented with a history of increased fatigability and generalised weakness since past 2 months. Her parents told that around 8 years of age, she had become very sick with severe respiratory distress requiring hospitalisation and ventilation for 7 days after which she improved to her usual state of health. On repeated questioning, the parents only remembered that she was otherwise normal but would tire out easily and not be as physically active as other children of her age group.

She was born out of a consanguineous marriage with uneventful neonatal period and showed normal gain of various developmental milestones. Family belonged to the state of Jammu and Kashmir, in Northern India. There was no family history of similar complaints. On examination, her weight and height were $14 \mathrm{~kg}$ and $115 \mathrm{~cm}$, respectively, (less than 3rd centile by Indian Academy of Pediatrics charts) suggesting acute on chronic malnutrition. There was no pallor, pedal oedema or abnormal heart sounds. She had elongated expressionless face with bilateral symmetrical ptosis (apparently unnoticed by parents) (figure 1). Motor examination showed power of grade $4 / 5$ at shoulder and hip joints suggestive of mild proximal weakness. The deep tendon reflexes were preserved. On careful observation, we found her to be using neck movements more than eye while following objects, with neck being kept slightly extended. This led us to re-examine her which showed some limitation of eyeball movements towards the extremes in all directions of gaze. Sensory system examination was unremarkable. There were no contractures, tongue fasciculations, myotonia and cerebellar signs.

Neuromuscular disorders with involvement of ocular muscles such as moebius syndrome, mitochondrial myopathies or myasthenia were considered as possibilities. As the weakness appeared to be fluctuating in nature, myasthenia seemed likely. An ophthalmology consultation revealed that her Cogan lid test was positive. It was elicited by having the patient look in downgaze followed by up gaze. As the affected eye saccades up, upper lid overshoots (video 1). Hypokalemic or hyperkalemic periodic paralysis should also be considered

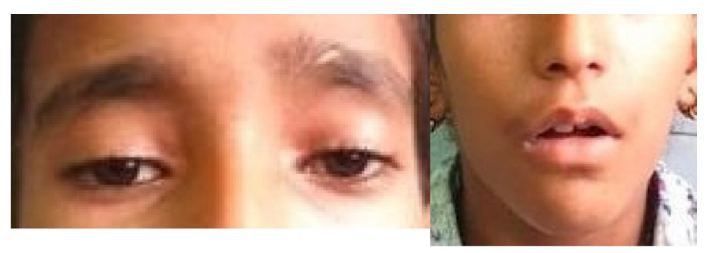

Figure 1 Bilateral symmetrical ptosis and facial weakness.

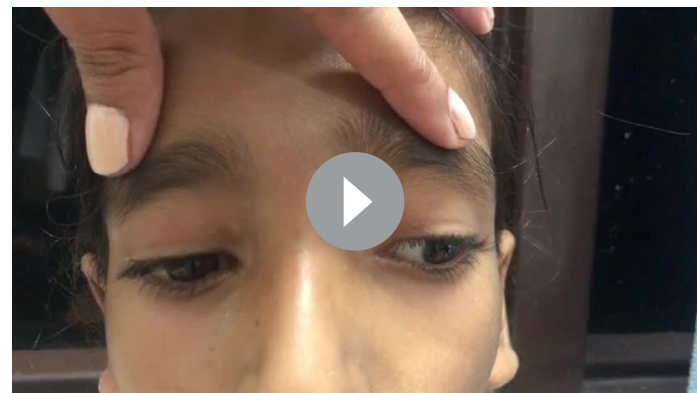

Video 1 Cogan lid test.

in cases with periodic attacks of acute flaccid paralysis. However, unlike our case, the permanent weakness in such disorders is usually seen in older ages.

Investigations showed creatine phosphokinase to be $47 \mathrm{U} / \mathrm{L}$ (normal range $26-180 \mathrm{U} / \mathrm{L}$ ) and lactate to be $0.8 \mathrm{mmol} / \mathrm{L}$ (normal range $<2 \mathrm{mmol} / \mathrm{L}$ ). Repetitive nerve stimulation test at $3 \mathrm{~Hz}$ was suggestive of decremental response and improvement with neostigmine. Acetylcholine receptor antibody and anti-Musk antibody were absent. Exome sequencing showed a pathogenic homozygous indel variant in exon 2 of CHRNE gene (chr 17:4805974 $\mathrm{T}>\mathrm{TC}$ ) by insertion of guanine at 130 coding position (c.130 131insG) which is predicted to cause a frameshift and consequent premature truncation of the protein (p.Glu44fs) confirming presence of congenital myasthenic syndrome (CMS) 4B (fast channel) or 4C (acetylcholine receptor deficiency). The child was started on oral pyridostigmine and is showing some signs of improvement.

CMSs comprise of phenotypically and genetically heterogenous diseases caused due to neuromuscular transmission dysfunction. Till date, 32 genes causing CMS have been described. ${ }^{1}$ Although named congenital, disease onset may be in infancy, childhood or rarely in adolescence. Phenotypically various subtypes share fatigability and weakness as common features.

CHRNE gene mutations and in particular the variant found in our child has been found at a high frequency (around 30\%) in patients of CMS in Brazilian and Spanish populations. ${ }^{23}$ Opthalmoparesis as seen in our child is a universal finding with CHRNE gene mutations and the disease appears to follow a relatively benign natural course in patients with c.130dupG. ${ }^{23}$

CMS are one of the rare examples of treatable genetic neuromuscular diseases. Although pyridostigmine is effective for CHRNE gene mutation subtype of CMS, in some other subtypes it can make symptoms worse. ${ }^{4}$ Hence, genetic testing not 
only confirms the clinical diagnosis but is also required for the correct treatment approach in CMS. ${ }^{5}$

\section{Patient's perspective}

We were really anxious, since our daughter was requiring multiple hospital admissions. Last time had to be ventilated; however, we were not clear about the underlying problem. After starting pyridostigmine she is showing signs of improvement and did not require any further hospitalisation.

\section{Learning points}

- Fluctuating weakness especially in young children is likely to be missed.

- One should consider myasthenia, hypohyperkalemic periodic paralysis, metabolic myopathies and toxin exposures in such cases.

- Congenital myasthenic syndromes (CMSs) though named congenital have variable age of onset from birth to adulthood.

- CMSs are one of the rare examples of a treatable genetic neuromuscular disease, and therefore receiving a correct genetic diagnosis allows patients to be started on effective therapy.
Acknowledgements We are thankful to the patient's family for permitting us to publish patient details and photographs.

Contributors Am K: patient management, literature review and manuscript preparation, CC: patient management, follow up and literature review, AM: literature review and patient management, An K: Clinician in-charge, critical review of the manuscript and final approval of the version to be published.

Funding The authors have not declared a specific grant for this research from any funding agency in the public, commercial or not-for-profit sectors.

Competing interests None declared.

Patient consent for publication Parental/guardian consent obtained.

Provenance and peer review Not commissioned; externally peer reviewed.

\section{ORCID iDs}

Amrit Kaur http://orcid.org/0000-0001-5751-6022

Chakshu Chaudhry http://orcid.org/0000-0002-0080-2172

Aditi Mehta http://orcid.org/0000-0003-0891-8169

\section{REFERENCES}

1 Finsterer J. Congenital myasthenic syndromes. Orphanet J Rare Dis 2019;14:57.

2 Estephan EdeP, Sobreira CFdaR, Dos Santos ACJ, et al. A common CHRNE mutation in Brazilian patients with congenital myasthenic syndrome. J Neurol 2018;265:708-13.

3 Natera-de Benito D, Töpf A, Vilchez JJ, et al. Molecular characterization of congenital myasthenic syndromes in Spain. Neuromuscul Disord 2017;27:1087-98.

4 Engel AG, Shen X-M, Selcen D, et al. Congenital myasthenic syndromes: pathogenesis, diagnosis, and treatment. Lancet Neurol 2015;14:420-34.

5 Thompson R, Bonne G, Missier P, et al. Targeted therapies for congenital myasthenic syndromes: systematic review and steps towards a treatabolome. Emerg Top Life Sci 2019;3:19-37.

Copyright 2020 BMJ Publishing Group. All rights reserved. For permission to reuse any of this content visit https://www.bmj.com/company/products-services/rights-and-licensing/permissions/

BMJ Case Report Fellows may re-use this article for personal use and teaching without any further permission.

Become a Fellow of BMJ Case Reports today and you can:

- Submit as many cases as you like

- Enjoy fast sympathetic peer review and rapid publication of accepted articles

- Access all the published articles

Re-use any of the published material for personal use and teaching without further permission

\section{Customer Service}

If you have any further queries about your subscription, please contact our customer services team on +44 (0) 2071111105 or via email at support@bmj.com.

Visit casereports.bmj.com for more articles like this and to become a Fellow 